\title{
SLC29A1 Gene
}

National Cancer Institute

\section{Source}

National Cancer Institute. SLC29A1 Gene. NCI Thesaurus. Code C105061.

This gene is involved in mediating the cellular uptake of nucleosides. 